\title{
Empowering Thalassemia Patients and Family to Increase Public Knowledge on Thalassemia
}

\section{Peter Asa ${ }^{1}$, Danti Nur Indiastuti ${ }^{2,4}$, Mia Ratwita Andarsini ${ }^{3,4}$, Jihan Nur Fauziyah' ${ }^{1}$, Annette d'Arqom ${ }^{2,4 *}$}

${ }^{1}$ Medical Study Program, Faculty of Medicine, Universitas Airlangga, Surabaya, Indonesia

${ }^{2}$ Division of Pharmacology, Department of Anatomy, Histology, and Pharmacology, Faculty of Medicine, Universitas Airlangga, Surabaya, Indonesia

${ }^{3}$ Department of Child Health, Faculty of Medicine Universitas Airlangga/Dr. Soetomo General Hospital, Surabaya, Indonesia

${ }^{4}$ Translational Medicine and Therapeutic Research Unit, Faculty of Medicine, Universitas Airlangga, Surabaya, Indonesia

Submitted: September 23 th 2021; Revised: November 19rd 2021; Accepted: November 27 2021

Keywords:
Education
Health
Online
Questionnaire
Reduced
inequalities
Thalassemia

\begin{abstract}
Thalassemia, the fifth-most catastrophic disease with 10,555 patients, causes physical, emotional, and economic burden for the patient, their family, and the country. Annually, IDR 500 billion are needed to cover the treatment of thalassemia. This projected number will continue to increase if no action is taken, so education and knowledge dissemination are important for thalassemia prevention. This community development involves thalassemia patients and families as partners and encourages them to share their knowledge and experience about thalassemia with the Indonesian late adolescents, young adult, and middle-aged adult population through an online webinar to increase public knowledge on thalassemia. Education media, such as posters and videos, were developed and disseminated during the activity, followed by live sharing from thalassemia patients, parents, and pediatricians. The respondents' knowledge of thalassemia was measured using an 11-items questionnaire before and after the online educational activity. The results show that the respondents have a good knowledge of thalassemia, and it increases after attending online education event about the disease $(9.74+2.4,10.22+0.77$, $\mathrm{p}<0.001)$. Their knowledge was associated with health-related field experience, knowing someone with thalassemia, and their willingness to undergo thalassemia testing $(p<0.046,0.013$, and 0.007 , respectively). Thus, these findings support the importance of education and dissemination of information regarding Thalassemia. Moreover, strong knowledge might lead to a willingness to undergo thalassemia testing, which might lead to less marriage between carriers and, eventually, a reduction in the incidence of thalassemia major.
\end{abstract}

\section{INTRODUCTION}

Thalassemia is one of the most common monogenic diseases in Southeast Asia, including Indonesia (Bajwa \& Basit, 2021). This genetic disease is caused by genetic mutations in the $\alpha$ - and $\beta$-globin genes that encode $\alpha$ - and $\beta$-globin proteins and hence lead to the composition of hemogoblin. This mutation further leads to the reduction or abolishment of the patient's hemogoblin. Therefore, the main symptom is anemia, which ranges from moderate to severe. Regular monthly transfusions and iron chelation consumptions are required to minimize iron deposition in many organs (d'Arqom, 2020; Thein, 2017).

Early detection before marriage and genetic screening are necessary to stop or reduce the escalation of this genetic disease. Several countries that have succeeded in reducing thalassemia rates to around $0 \%$ are Cyprus and Italy, which have launched prevention

ISSN 2460-9447 (print), ISSN 2541-5883 (online)

${ }^{*}$ Corresponding author : Annette d'Arqom

Department of Anatomy, Histology, and Pharmacology, Faculty of Medicine, Universitas Airlangga, Jl. Mayjen Prof. Dr. Moestopo No. 47, Surabaya, East Java 60131, Indonesia

Email: annette-d-a@fk.unair.ac.id 
programs since 1980. The first two things done are massive education and thalassemia mutant carriers' detection in every population (Cao \& Kan, 2013). Patients with Thalassemia in East Java continue to increase, from 170 patients in 2007 to 470 patients in 2015 and 510 patients in 2021 (Purnomo, 2021). Moreover, the rate of early marriage in Indonesia is considerably high. Basic health survey data in 2010 showed that $0.2 \%$ of women aged $10-14$ years, $11.7 \%$ of women aged 15-19 years, and $>56.2 \%$ of women aged 20-24 years were married (RISKESDAS, 2010) Therefore, education is needed regarding the introduction of the status and risk of this disease from an early age, before marriage, to cut the chain of thalassemia. It is necessary to disseminate information and education to overcome the problems above. One possible way is by empowering the patient and their family to actively disseminate their experience and view about thalassemia. This move may result in advantages by convincing the community to do thalassemia screening. Therefore, this study aims to to explore the effectiveness of online education led by thalassemia patients and families with the associated sociodemographic factors.

\section{METHOD}

\subsection{Study design and data collection}

This cross-sectional study was approved by the Ethical Committee of Faculty of Medicine, Universitas Airlangga with the official letter number 39/EC/KEPK/FKUA/2021. The respondents of this study were Indonesian late adolescents, young adults, and middle-aged adults. Eighteen thalassemia patients and families developed education media based on their experience, spirit, and challenges of living with thalassemia. Short essays, videos, paintings, and posters were among the educational media disseminated during an online webinar on June 13, 2021. Each education media, a total of nine media, were displayed for 5 minutes with short explanations. Following the dissemination of educational media, live sharing and discussion sessions from a thalassemia patient, a parent with thalassemia children, and a pediatrician consultant in oncology and hematology were conducted. The respondents' knowledge on thalassemia was measured using an 11-item questionnaire before and after the online activity. Respondents' and/or parents' informed consents were collected prior to the activity.

\subsection{Survey Instrument}

The respondents' knowledge of thalassemia was measured by using a set of questionnaires before and after the online activity. The questionnaire was validated by two medical doctors and one pediatrician consultant of oncology and hematology. Face validity was measured in 75 respondents. They were asked to evaluate their understanding of the questions, including their wording and format, after completing the form. The questionnaire consists of three sections, namely the basic information of the respondents, eleven closedended questions on knowledge regarding thalassemia, and the respondents' experience and willingness to do thalassemia screening.

\subsection{Analytical Procedure}

The answers of the knowledge were measured using yes/no/does not know options which measured as $1 / 0 / 0$. The total score was the summation of the score of 11 questions. Normality test was measured first, followed by the correlation between each score and each respondent's total score of for each question. Furthermore, Spearman's correlation test was performed to measure the internal consistency by comparing each question with the total score. Moreover, the reliability was conducted by calculating Cronbach's alpha. After validating the questionnaire, the questionnaire was further used to measure the respondent's knowledge before and after the online activity. The quantitative data were descriptively analyzed using Graph PRISM version 5.00 (La Jolla, California USA) and SPSS 25.00 (IBM, Chicago, IL).

\section{RESULT AND DISCUSSION}

\subsection{Development of education materials}

The patients and the family had prepared several education materials, such as posters, videos, Instagram content, etc prior to the online seminar (Figure 1) These materials were then delivered during the online seminar and it was followed by the live sharing session from the hematologic pediatrician, thalassemia patients, and the parents of children with thalassemia These education materials and the live sharing session explained the definition of thalassemia, genetic mechanism, symptoms, screening, and the patients and their families' perspectives on it.

\subsection{Development of Questionnaire}

The normality test from 75 respondents showed that the data was not normally distributed, so Spearman's correlation test was performed to measure the validity (Table 1). Since all the r-values were higher than the r-table $(0.191)$, all questions were valid to measure the knowledge regarding thalassemia. Moreover, Cronbach's alpha test was performed to measure the internal consistency, and the result showed 0.884 , which can be concluded that the questionnaire was reliable to measure knowledge regarding thalassemia.

\subsection{The increasing thalassemia knowledge after online educational activity and respondent's screening experience and willingness}

One hundred and six respondents have joined the online educational activity. However, only fifty-four respondents completed the pre and post-test. The 


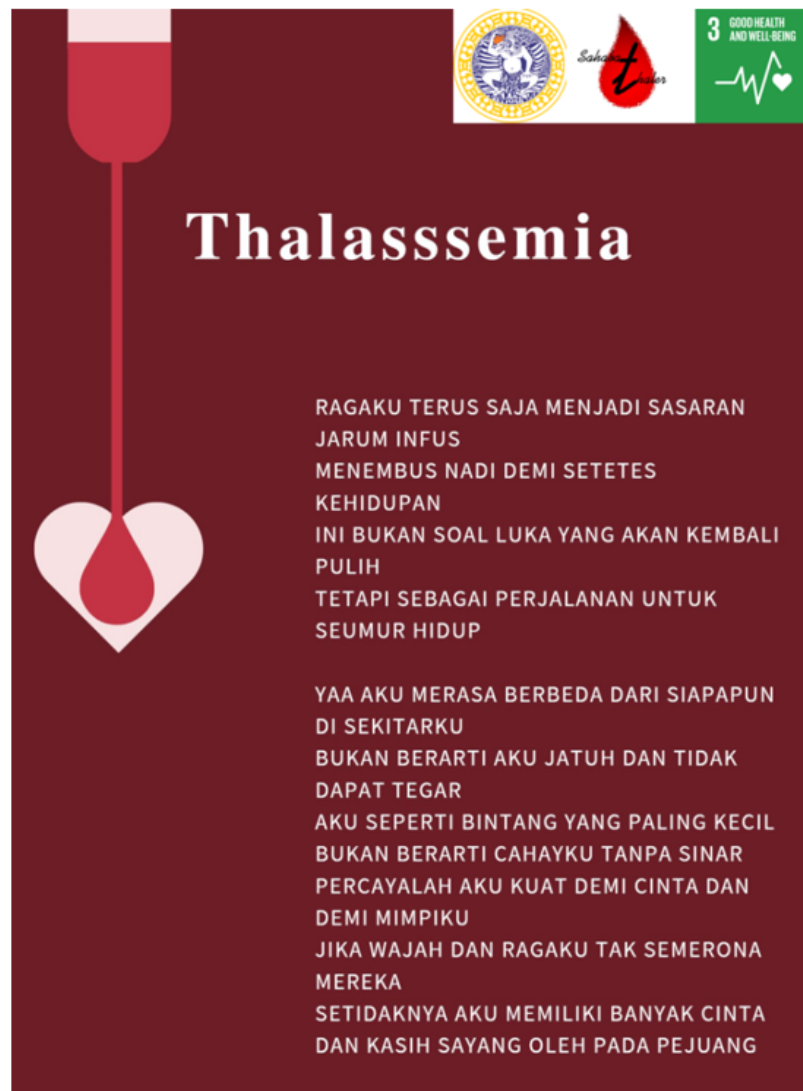

\section{Ketidakmerataan Fasilitas dan Kebijakan}

"Tantangan terbesar bagi para Thaler (Thalassemia

Mayor) adalah TIDAK MERATANYA fasilitas

kesehatan dan kebijakan di Rumah Sakit, misalnya pada

batasan Hemoglobin yang harus mendapatkan transfusi."

"Tidak jarang para Thaler dan keluarga

DITOLAK, karena $\mathrm{Hb}$ masih 8 atau 9

g/dL. Padahal Hb normal adalah kunci pertumbuhan dan perkembangan

optimal.

Figure 1. Example of education materials developed by thalassemia patients and family

respondents came from various backgrounds, with the majority being young adolescents $(72 \%)$ and females $(76 \%)$. Based on residence, $52 \%$ of respondents resided outside Java Island, the main island in Indonesia. More than half were working or had family or acquaintances who work in a health-related field $(57 \%)$ and knew thalassemia patients (54\%). The sociodemographic characteristics of respondents are summarized in Table 2.

The result showed that the knowledge of the respondents was good $(9.74+2.4)$ and significantly increased after the online educational activity with thalassemia patients and families $(10.22+1.77$, $\mathrm{p}<0.001$, Figure 2.a). Moreover, Fisher's exact test was performed to find an association between sociodemographic factors and knowledge. The results showed that working or having family or acquaintances that work in the health-related field was associated with the higher score of pre-test and post-test. However, it was not associated with knowledge change $(\mathrm{p}<0.046$ and $\mathrm{p}<0.027$, respectively). Knowing Thalassemia patients was also associated with higher knowledge on the pre-test score $(\mathrm{p}<0.013)$, but not on the post-test and the knowledge change. The other sociodemographic factors, namely age, gender, residence, and economic factors, were not associated with thalassemia knowledge (Table 2).

Respondents were further asked regarding thalassemia screening and willingness. As expected, the majority of the respondents $(72 \%)$ had never been screened for thalassemia and did not know their thalassemia status. Twenty percent of respondents had previously checked their genetic status for thalassemia (Figure 2.b). After the online educational activity, 79\% of respondents were willing to check their genetic status for thalassemia (Figure 2.c). Their willingness was significantly associated with their pre-test score $(\mathrm{p}<0.007$, Table 2).

Table 1. Validity of thalassemia knowledge questionnaire

\begin{tabular}{|c|c|c|c|}
\hline Item & $\mathbf{r}$ & sig & Interpretation \\
\hline Q1: Can thalassemia be inherited from one or both parents? & .650 & .000 & Valid \\
\hline Q2: Is thalassemia an infectious disease? & 609 & .000 & Valid \\
\hline Q3: Is thalassemia a disease with a defect in red blood cells? & .580 & .000 & Valid \\
\hline Q4: Is thalassemia similar to blood cancer? & .685 & .000 & Valid \\
\hline Q5: Are anemia, fatigue, pale skin, and yellow sclera the symptoms of thalassemia? & .528 & .000 & Valid \\
\hline Q6: Is all anemia thalassemia? & .499 & .000 & Valid \\
\hline Q7: Do the patients of thalassemia major need blood transfusion for the rest of their lives? & .717 & .000 & Valid \\
\hline Q8: Can thalassemia be prevented by not marrying a thalassemia carrier or patient? & .718 & .000 & Valid \\
\hline $\begin{array}{l}\text { Q9: Does knowing the history of thalassemia in the family, repeated blood transfusion, anemia, and blood } \\
\text { checking can help to diagnose thalassemia? }\end{array}$ & .557 & .000 & Valid \\
\hline Q10: Can blood donation help thalassemia patients? & .587 & .000 & Valid \\
\hline $\begin{array}{l}\text { Q11: Can negative stigma, economic problems, and physical changes cause mental illness for thalassemia } \\
\text { patients? }\end{array}$ & .428 & .000 & Valid \\
\hline
\end{tabular}




\begin{tabular}{|c|c|c|c|c|c|c|c|}
\hline \multirow[t]{2}{*}{ Characteristic } & \multirow[t]{2}{*}{ Number [\%] } & \multicolumn{2}{|c|}{ Pre-test } & \multicolumn{2}{|c|}{ Post-test } & \multicolumn{2}{|c|}{ Changing of Knowledge } \\
\hline & & $\begin{array}{l}\text { Fisher's exact } \\
\text { value }\end{array}$ & p-value & $\begin{array}{l}\text { Fisher's exact } \\
\text { value }\end{array}$ & p-value & $\begin{array}{l}\text { Fisher's exact } \\
\text { value }\end{array}$ & p-value \\
\hline Age & & 19.156 & .739 & 15.098 & .586 & 21.515 & .852 \\
\hline$<18$ y.o & $3[6]$ & & & & & & \\
\hline $18-20$ y.o & $11[20]$ & & & & & & \\
\hline $20-25$ y.o & $28[52]$ & & & & & & \\
\hline$>25$ y.o & $12[22]$ & & & & & & \\
\hline Gender & & 3.189 & .947 & 4.519 & .548 & 6.961 & .565 \\
\hline Male & $13[24]$ & & & & & & \\
\hline Female & $41[76]$ & & & & & & \\
\hline Place of residence & & 5.632 & .702 & 3.817 & .661 & 7.941 & .416 \\
\hline Java & $26[48]$ & & & & & & \\
\hline Outside Java & $28[52]$ & & & & & & \\
\hline Marriage status & & 6.323 & .495 & 4.862 & .505 & 7.240 & .525 \\
\hline Married & 12 [22] & & & & & & \\
\hline Not married & $42[78]$ & & & & & & \\
\hline Economy & & 24.746 & .170 & 17.203 & .308 & 27.312 & .274 \\
\hline$<$ Average & $1[2]$ & & & & & & \\
\hline Average & $50[93]$ & & & & & & \\
\hline$>$ Average & $3[6]$ & & & & & & \\
\hline $\begin{array}{l}\text { Work or have family w } \\
\text { related field }\end{array}$ & in health- & 11.218 & .046 & 9.758 & .027 & 8.628 & .314 \\
\hline Yes & $31[57]$ & & & & & & \\
\hline No & $23[43]$ & & & & & & \\
\hline \multicolumn{8}{|c|}{ Knowing thalassemia patients } \\
\hline Yes & $29[54]$ & 13.397 & .013 & 5.005 & .373 & 10.464 & .120 \\
\hline No & $25[46]$ & & & & & & \\
\hline \multicolumn{8}{|l|}{ Screening Experience } \\
\hline Never & 39 [72] & 17.102 & .212 & 11.602 & .365 & 13.583 & .815 \\
\hline Ever & $11[20]$ & & & & & & \\
\hline Do not know & $4[7]$ & & & & & & \\
\hline Screening Willingness & & 26.645 & .007 & 14.341 & .191 & 20.989 & .209 \\
\hline No & $8[15]$ & & & & & & \\
\hline Yes & $80[80]$ & & & & & & \\
\hline Do not know & $3[6]$ & & & & & & \\
\hline
\end{tabular}

Note: Boldface p-values indicate a significant association between sociodemographic factors and thalassemia knowledge score.
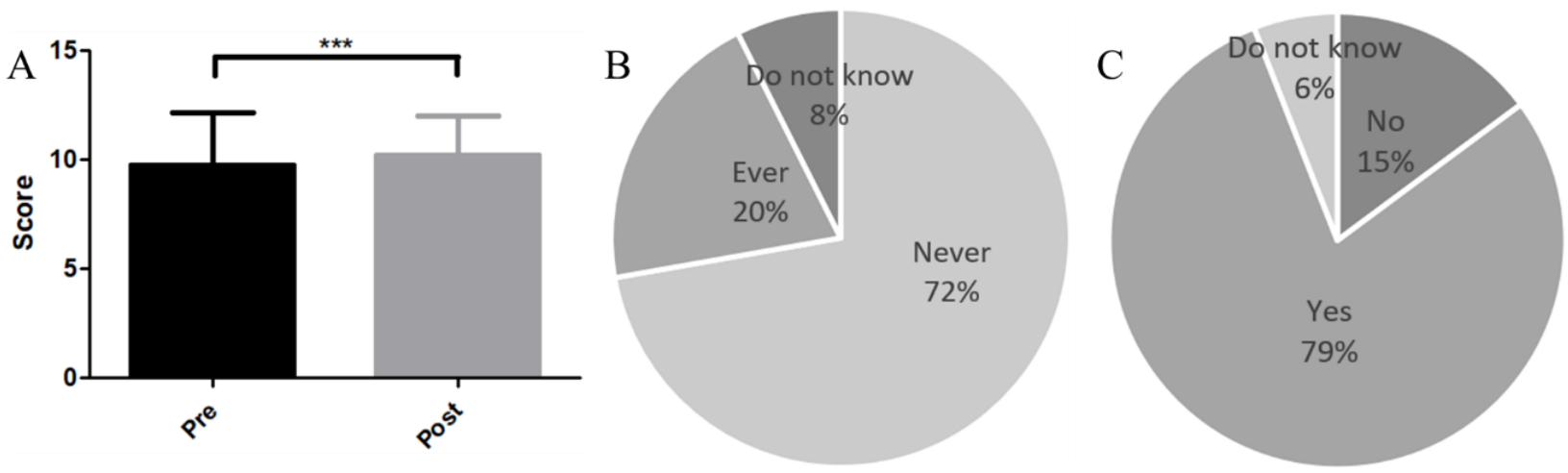

Figure 2. Respondent's knowledge of thalassemia, screening experience, dan willingness. a) The pre-test and the post-test score of knowledge on thalassemia. P-value $<0.001 ; b)$ The number of respondents that has undergone thalassemia screening and knows their genetic status of thalassemia; c) Willingness to undergo thalassemia screening.

\subsection{Discussion}

Thalassemia is the most common genetic disease in Indonesia, with $3-5 \%$ of the population having the chance of carrying the genetic pitfall (Fucharoen \& Winichagoon, 1992). The knowledge about this disease, including the basic ones, the inheritance, the possibility, and the prevention, is a first key point to stop the increase of thalassemia case (Cao \& Kan, 2013). This condition imposes not only physical burden but also an emotional and economic burden on the patient, their family, and the country (Colah et al., 2017; Riewpaiboon et al., 2010; Thiyagarajan et al., 2019). It is important to empower thalassemia patients and their families that have experience with this disease to convince the audience.

In this study, we developed and validated an 11item questionnaire to measure the respondents' knowledge regarding thalassemia and further measure the knowledge of respondents after online educational activity aimed at empowering thalassemia patients and families. Our findings support a prior study in which high school students had strong knowledge about thalassemia, even though their knowledge was not correlated with their understanding (d'Arqom et al., 2021). Their knowledge rose after the online educational activity, and it was associated with healthrelated field experience as well as knowing someone 
with thalassemia. This finding supports the importance of education and dissemination of information regarding thalassemia. Moreover, strong knowledge leads to a willingness to do thalassemia testing, which might lead to reduced marriages between carriers and reduce the incidences of thalassemia major (Wong et al., 2011). The results of our study are similar to the finding of a study on 179 medical students, which demonstrates that a higher thalassemia knowledge score makes medical students more likely to undergo thalassemia carrier status testing (Dewanto et al., 2015).

This community development emphasized the benefits of the prevention program, which according to the experience of other countries, puts the cost required for this education and the screening or genetic testing much lower than the cost for treating thalassemia that reaches more than IDR 500 billion in 2019 (Koren et al., 2014; Ostrowsky et al., 1985; PTPTM, 2019). This study, like many other studies involving healthcare professionals, community volunteers, and high school cadres (Cheng et al., 2018; d'Arqom et al., 2021; Jopang et al., 2015), shows that empowering thalassemia patients and their families is an effective method to increase community's knowledge of thalassemia and convince them about the importance of knowing their thalassemia status. However, due to the limited sample size in this study, a further study in the broader community is necessary to measure the effectiveness of this method before it is implemented in society.

\section{CONCLUSION}

Since thalassemia is the most common genetic disease in the Asian region, including Indonesia, and causes physical, emotional, and economic burden to the patient, their family, and their country, prevention is the most effective way to lessen this burden. Our study supports the importance of education on thalassemia, particularly through empowering patients and their families, in educating the community about the negative effects of this genetic disease. With a good understanding, there is a greater willingness to do screening, which might eventually lead to fewer marriage between high-risk couples and a reduction in the overall number of thalassemia major cases. Therefore, multisectoral collaboration involving patients and their families is needed to achieve zero birth of thalassemia major.

\section{ACKNOWLEDGMENT}

We would like to thank Persatuan Orang Tua Penderita Talasemia Indonesia (POPTI) regional Surabaya, Andi Cahyadi, Kusuma Eko Purwantari, and Nurmawati Fatimah for their support through this study. This study was funded by Rencana Kerja dan Anggaran Tahunan (RKAT) Faculty of Medicine
Universitas Airlangga as the Rector's Decree No. 388/UN3/2021

\section{REFERENCES}

Bajwa, H., \& Basit, H. (2021). Thalassemia. Treasure Island (FL): StatPearls Publishing.

Cao, A., \& Kan, Y. W. (2013). The prevention of thalassemia. Cold Spring Harbor Perspectives in Medicine, 3(2), a011775-a011775. doi:10.1101/cshperspect.a011775

Cheng, K., Fucharoen, S., Sanchaisuriya, K., Fucharoen, G., Sanchaisuriya, P., \& Jetsrisuparb, A. (2018). Effect of health education on severe thalassemia prevention and control in communities in Cambodia. Archives of Public Health, 76(1), 13. doi:10.1186/s13690-0180259-3

Colah, R., Italia, K., \& Gorakshakar, A. (2017). Burden of thalassemia in India: The road map for control. Pediatric Hematology Oncology Journal, 2(4), 79-84. https://doi.org/10.1016/j.phoj.2017.10.002

d'Arqom, A. (2020). Nucleic acid therapy for $\beta$ thalassemia. Biologics : Targets \& Therapy, 14, 95-105. https://doi:10.2147/BTT.S265767

d'Arqom, A., Indiastuti, D. N., \& Nasution, Z. (2021). Online peer-group activism for thalassemia health education during the COVID-19 pandemic: a case study from East Java, Indonesia. Journal of Health Research, aheadof-print(ahead-of-print).

https://doi:10.1108/JHR-09-2020-0442

Dewanto, J. B., Tansah, H., Dewi, S. P., Napitu, H., Panigoro, R., \& Sahiratmadja, E. (2015). Increased knowledge of thalassemia promotes early carrier status examination among medical students. Universa Medicina, 34(3), 220-228. https://doi:10.18051/UnivMed.2015.v34.220228

Fucharoen, S., \& Winichagoon, P. (1992). Thalassemia in SouthEast Asia: problems and strategy for prevention and control. Southeast Asian Journal of Tropical Medicine and Public Health, 23(4), 647-655.

Jopang, Y., Petchmark, S., Jetsrisuparb, A., Sanchaisuriya, K., Sanchaisuriya, P., \& Schelp, F. P. (2015). Community participation for thalassemia prevention initiated by village health volunteers in Northeastern Thailand. Asia Pacific Journal of Public Health, 27(2), NP2144-NP2156. https://doi:10.1177/1010539511430520

Koren, A., Profeta, L., Zalman, L., Palmor, H., Levin, C., \& Zamir, R. B. (2014). Prevention of beta Thalassemia in Northern Israel - a cost-benefit analysis. Mediterranean Journal of Hematology and Infectious Diseases, 6. https://doi:10.4084/mjhid.2014.012

Ostrowsky, J. T., Lippman, A., \& Scriver, C. R. (1985). Cost-benefit analysis of a thalassemia disease prevention program. American Journal of Public 
Health,

75(7),

732-736.

https://doi:10.2105/ajph.75.7.732

PTPTM. (2019). Talasemia, Penyakit Berbiaya Tinggi ke-5 di Indonesia. Retrieved from http://p2ptm.kemkes.go.id/kegiatan-p2ptm/dkijakarta/talasemia-penyakit-berbiaya-tinggi-ke5-di-indonesia

Purnomo (2021). [Interview: Thalassemia in East Java].

Riewpaiboon, A., Nuchprayoon, I., Torcharus, K., Indaratna, K., Thavorncharoensap, M., \& Ubol, B. (2010). Economic burden of betathalassemia/Hb E and beta-thalassemia major in Thai children. BMC Research Notes, 3(1), 29. https://doi:10.1186/1756-0500-3-29

RISKESDAS. (2010). Riset Kesehatan Dasar. Retrieved from http://kesga.kemkes.go.id/images/pedoman/Risk esdas $\% 202010 \% 20$ Nasional.pdf

Thein, S. L. (2017). Molecular basis of $\beta$ thalassemia and potential therapeutic targets. Blood Cells, Molecules, and Diseases. https://dx.doi.org/10.1016/j.bcmd.2017.06.001

Thiyagarajan, A., Bagavandas, M., \& Kosalram, K. (2019). Assessing the role of family well-being on the quality of life of Indian children with thalassemia. BMC Pediatrics, 19(1), 100-100. https://doi:10.1186/s12887-019-1466-y

Wong, L. P., George, E., \& Tan, J.-A. M. A. (2011). A holistic approach to education programs in thalassemia for a multi-ethnic population: consideration of perspectives, attitudes, and perceived needs. Journal of Community Genetics, 2(2), 71-79. https://doi:10.1007/s12687-011-0039-z 